\title{
PENGARUH PENGGUNAAN MEDIA BUKU SAKU KESPRO TERHADAP PELAKSANAAN PEMERIKSAAN PAYUDARA SENDIRI (SADARI) OLEH REMAJA DI SMAN I CIPANAS KABUPATEN LEBAK TAHUN 2015
}

\author{
*Yayah Rokayah, *Siti Rusyanti'
}

\begin{abstract}
Abstrak
Kanker payudara merupakan masalah kesehatan masyarakat yang penting karena mortalitas dan morbiditasnya yang tinggi. Pemeriksaan payudara sendiri (SADARI) perlu dikuasai dan dilakukan oleh remaja putri agar dapat melakukan deteksi dini kanker payudara. Salah satu upaya untuk meningkatkan pengetahuan dan keterampilan SADARI remaja adalah melalui penyuluhan SADARI dengan menggunakan media buku saku kesehatan reproduksi remaja. Banyak faktor yang menjadi penyebab mengapa hanya sebagian kecil wanita yang melakukan SADARI, diantaranya kepatuhan mereka yang dapat dipengaruhi oleh ketersediaan media. Oleh karena itu penelitian ini bertujuan mengetahui pengaruh penggunaan media buku saku kesehatan reproduksi dalam pelaksanaan SADARI oleh remaja di SMAN 1 Cipanas Kabupaten Lebak.

Penelitian dirancang menggunakan desain penelitian Kohort. Besar sampel sebanyak 108 responden. Data dianalisis menggunakan uji Chi Square

Hasil penelitian menunjukkan bahwa sebagian besar $(91,7 \%)$ responden menggunakan media buku saku kesehatan reproduksi. Hanya sebagian kecil $(6,5 \%)$ responden yang melakukan Pemeriksaan Payudara Sendiri (SADARI). Pada uji statistik (uji chi square) diperoleh hasil $\mathrm{p}=1,000$ artinya tidak ada perbedaan bermakna pada kedua variabel tersebut atau tidak ada hubungan yang signifikan antara penggunaan media buku saku kesehatan reproduksi remaja dengan pelaksanaan Pemeriksaan Payudara Sendiri (SADARI) oleh responden.

Selain media buku saku kesehatan reproduksi, disarankan perlu media lain seperti Pusat Informasi, Konseling Remaja \& Mahasiswa (PIK R/M) dan pemberian informasi melalui penyuluhan kesehatan reproduksi remajadi sekolah secara periodik.
\end{abstract}

Kata Kunci: Buku saku, SADARI.

*Poltekkes Kemenkes Banten 
Pendahuluan

Kanker payudara merupakan masalah kesehatan masyarakat yang penting karena mortalitas dan morbiditasnya yang tinggi. Jumlah kasus kanker payudara di dunia menduduki peringkat kedua setelah kanker serviks, disamping itu kanker payudara menjadi salah satu pembunuh utama wanita di dunia dan adanya kecenderungan peningkatan kasus baik di dunia maupun di Indonesia.

Penyebab pasti kanker payudara belum diketahui, diperkirakan multifaktorial. Proses timbulnya kanker payudara merupakan kejadian kompleks yang melibatkan berbagai faktor.

Kejadian kanker payudara akan meningkat cepat pada usia reproduktif, kemudian setelah itu meningkat dengan kecepatan yang lebih rendah. Pendidikan dan jenis pekerjaan tidak berpengaruh terhadap kejadian kanker payudara. Proporsi terbanyak pada stadium III menunjukkan bahwa kesadaran masyarakat untuk melakukan pengobatan pada gejala awal atau pada stadium dini masih sangat rendah.

Kebanyakan masyarakat tidak mengetahui gejala kanker payudara, cara mendeteksi kanker payudara secara dini, pencarian pengobatan serta cara pencegahannya. Mereka berpendapat bahwa kanker payudara adalah merupakan penyakit keturunan saja.

Menurut (WHO 2005), penyakit kanker merupakan penyebab kematian nomor 2 setelah penyakit kardiovaskuler, setiap tahun terdapat 7 juta penderita kanker payudara dan 5 juta orang meninggal karena kanker payudara.

Profil Kesehatan Indonesia 2008 dari Departemen Kesehatan Republik Indonesia menyebutkan bahwa penyakit kanker payudara memiliki urutan pertama dari 10 penyakit kanker pada pasien rawat inap di RS tahun 2004 - 2007. Provinsi Banten termasuk 5 provinsi dengan prevalensi tumor dan kanker payudara melebihi angka prevalensi nasional yaitu $6,35 \%$. Angka prevalensi nasional adalah $5,03 \%$.

Kanker payudara menimbulkan rasa takut yang luar biasa bagi kaum perempuan karena selain menimbulkan kematian juga berpengaruh pada estetika. Deteksi yang terlambat dan kurangnya pengetahuan menyebabkan 
sebagian besar penderita kanker terlambat diobati.

Masalah kanker payudara di Indonesia menjadi lebih besar karena lebih dari $70 \%$ penderita kanker payudara datang ke dokter pada stadium yang sudah lanjut. Hal ini berbeda dengan di Jepang masalah kanker payudara lanjut hanya ditemukan sebanyak $13 \%$ (Sutjipto, 2008).

Pemeriksaan terhadap tumor atau kanker payudara dapat dilakukan sendiri dengan program SADARI. Pemeriksaan Payudara Sendiri (SADARI) untuk mendeteksi kanker payudara harus disosialisasikan lebih gencar. Ini adalah cara termudah dan termurah mengetahui adanya benjolan yang kemungkinan besar berkembang menjadi kanker ganas.

SADARI merupakan langkah penting untuk deteksi dini kanker payudara. Kebiasaan ini mudah, murah, cepat dan efektif untuk semakin "mengenal" dan menyadari jika terdapat suatu hal yang tidak normal pada payudara.

Pemeriksaan payudara sendiri perlu dikuasai dan dilakukan oleh remaja putri agar dapat melakukan deteksi dini kanker payudara. Salah satu upaya untuk meningkatkan pengetahuan dan ketrampilan SADARI remaja adalah melalui penyuluhan SADARI. Promosi Kesehatan di Sekolah ditambah dengan penggunaan media promosi merupakan langkah yang strategis dalam upaya peningkatan derajat kesehatan masyarakat hal ini didasari pemikiran bahwa sekolah merupakan lembaga yang sengaja didirikan untuk membina dan meningkatkan kualitas sumber daya manusia baik fisik mental maupun spiritual.

Penderita kanker payudara saat ini beranjak menyerang perempuan muda. Ada kecenderungan kanker payudara dialami oleh perempuan dengan usia 15-20 tahun, ini berarti sangat penting untuk memulai memberikan pendidikan kesehatan tentang SADARI (7-10 hari setelah haid) setiap bulan. Dengan melakukan pemeriksaan payudara sendiri (SADARI) akan menurunkan tingkat kematian akibat kanker payudara sampai $20 \%$, sayangnya wanita yang melakukan SADARI masih rendah (25\%-30\%).

Berdasarkan uraian di atas dan informasi kasus kanker dengan insiden tertinggi pada perempuan dengan 
kanker payudara, maka perlu adanya upaya pendeteksian dini kanker/tumor payudara pada tingkat sekolah menengah atas, karena pada tingkatan ini siswa merupakan remaja putri yang beresiko terkena kanker payudara

\section{Metodologi Penelitian}

Penelitian ini dirancang menggunakan desain kohort. Populasi penelitian ini adalah semua remaja siswi kelas 10 SMAN I Cipanas Kabupaten Lebak sebanyak 147 orang. Kriteria inklusi pemilihan sampel penelitian adalah siswa umur 15-20 tahun, bersedia menjadi sampel penelitian, dapat diajak komunikasi. Besar sampel 108 orang.

Jenis data adalah data primer yang diperoleh dengan menggunakan metode wawancara langsung berdasarkan kuesioner. Dilakukan analisis data univariat dan bivariat. Analisis data univariat dilakukan dengan mendeskripsikan semua variabel penelitian dalam bentuk tabel distribusi frekuensi. Analisis data bivariat Dilakukan untuk menjawab hipotesis penelitian dengan menggunakan uji Chi Square. Analisis tersebut dianggap bermakna jika $p$ value $\leq 0,05$, Ho ditolak dan $\mathrm{Ha}$ diterima yang berarti ada hubungan antara dua variabel tersebut.pvalue > 0,05, Ho diterima dan Ha ditolak yang berarti tidak ada hubungan antara dua variabel.

\section{Hasil}

\section{Analisis Univariat}

a. Penggunaan Media Buku Saku

Kesehatan Reproduksi Remaja

Tabel 4.1

Dist Frek Siswi SMAN 1 Cipanas

Berdasarkan Penggunaan Media Buku Saku Kesehatan Reproduksi Remaja Tahun 2015

\begin{tabular}{ccc}
\hline $\begin{array}{c}\text { Penggunaan } \\
\text { Buku Saku } \\
\text { Kespro }\end{array}$ & F & $\%$ \\
\hline Tidak & 9 & 8,3 \\
Ya & 99 & 91,7 \\
\hline Jumlah & 108 & 100 \\
\hline
\end{tabular}

Tabel 4.1 menunjukkan bahwa masih terdapat $(8,3 \%)$ responden tidak menggunakan media buku saku kesehatan reproduksi remaja.

b. Pelaksanaan Pemeriksaan Payudara Sendiri (SADARI)

Pelaksanaan Pemeriksaan Payudara Sendiri (SADARI) oleh responden dibagi dalam dua kategori melakukan, yaitu responden melakukan SADARI 1-3 kali dalam tiga bulan terakhir, serta tidak melakukan, yaitu responden tidak 
melakukan melakukan SADARI 1-3 kali dalam tiga bulan terakhir. Distribusi pelaksanaan Pemeriksaan Payudara Sendiri (SADARI)oleh responden dapat dilihat pada tabel berikut:

Tabel 4.2

Dist Frek Siswi SMAN 1 Cipanas Berdasarkan Pelaksanaan Pemeriksaan Payudara Sendiri

\begin{tabular}{llcc}
\multicolumn{4}{c}{ (SADARI) Tahun 2015} \\
\hline No & SADARI & $\mathrm{F}$ & $\%$ \\
\hline 1 & Tidak Melakukan & 101 & 93,5 \\
2 & Melakukan & 7 & 6,5 \\
\hline & Jumlah & 108 & 100
\end{tabular}

Tabel 4.2 menunjukkan bahwa hamper seluruh responden $(93,5 \%)$ tidak melakukan Pemeriksaan Payudara Sendiri (SADARI).

\section{Analisis Bivariat}

Hubungan antara penggunaan media buku saku kespro remaja dengan pelaksanaan SADARI

Tabel 4.3

Hubungan penggunaan media buku saku kespro remaja dengan pelaksanaan SADARI pada siswa SMAN 1 Cipanas Tahun 2015

\begin{tabular}{|c|c|c|c|c|c|c|}
\hline \multirow{3}{*}{$\begin{array}{l}\text { Penggunaan } \\
\text { media buku } \\
\text { saku }\end{array}$} & \multicolumn{4}{|c|}{ SADARI } & \multirow{2}{*}{\multicolumn{2}{|c|}{ Total }} \\
\hline & \multicolumn{2}{|c|}{ Tidak } & \multicolumn{2}{|c|}{$\mathrm{Ya}$} & & \\
\hline & $\mathrm{n}$ & $\%$ & $\mathrm{n}$ & $\%$ & $\mathrm{n}$ & $\%$ \\
\hline Tidak & 92 & 92,9 & 7 & 7,1 & 99 & 100 \\
\hline $\mathrm{Ya}$ & 9 & 100 & 0 & 0 & 9 & 100 \\
\hline Total & 101 & 93,5 & 7 & 6,5 & 108 & 100 \\
\hline \multicolumn{7}{|c|}{$p=1,00$} \\
\hline
\end{tabular}

Berdasarkan tabel silang 4.3 diketahui bahwa nilai $p$ pada analisis bivariat dengan uji chi square adalah 1,000 dapat diartikan bahwa tidak ada hubungan yang signifikan antara penggunaan media buku saku kesehatan reproduksi remaja dengan pelaksanaan Pemeriksaan Payudara Sendiri (SADARI) oleh responden

\section{Pembahasan}

Berdasarkan hasil penelitian sebelumnya yang dilakukan oleh Tri Viviyawati di SMKN 1 Karanganyar, bahwa ada pengaruh pendidikan kesehatan tentang pemeriksaan SADARI sebagai deteksi dini kanker payudara terhadap pengetahuan remaja putri.

Media cetak merupakan salah satu jenis paparan media yang mempengaruhi remaja. Media cetak memiliki kelebihan seperti tahan lama, mencakup banyak orang, biaya rendah, dapat dibawa kemana-mana, mempermudah pemahaman.

Secara teori Buku saku sebagai media penyuluhan yang efektif dalam upaya meningkatkan pengetahuan remaja, karena buku saku merupakan media cetak yang bisa memuat banyak tulisan gambar, dan praktis. Pendidikan kesehatan tentang SADARI sangat mempengaruhi terhadap sikap remaja 
putri. Pendidikan kesehatan merupakan suatu kegiatan yang dapat meningkatkan sikap dalam memelihara dan meningkatkan kesehatan mereka sendiri (Adnani, 2011).

Berdasarkan hasil penelitian mengenai pelaksanaan pemeriksaan payudara sendiri (SADARI) dapat disimpulkan bahwa hanya sebagian kecil (6,5\%) responden yang melakukan Pemeriksaan Payudara Sendiri (SADARI).

Perilaku adalah bentuk respon seseorang terhadap stimulus, namun dalam memberikan respon sangat tergantung pada karakteristik dari orang yang bersangkutan. Artinya meskipun stimulusnya sama pada beberapa orang, namun responnya berbeda tergantung dengan karakteristik masing-masing orang.

Untuk mewujudkan sikap menjadi suatu tindakan nyata diperlukan faktor pendukung atau suatu kondisi yang memungkinkan, antara lain fasilitas dan dukungan dari pihak lain.

Green menjelaskan bahwa prilaku dilatarbelakangi atau dipengaruhi oleh beberapa faktor diantaranya yaitu faktor predisposisi; pengetahuan. Berdasarkan pengalaman dan penelitian, perilaku yang didasari oleh pengetahuan akan lebih langgeng daripada perilaku yang tidak didasari oleh pengetahuan (Notoatmodjo, 2007).

Pada penelitian ini, diperoleh hasil analisis bahwa tidak ada hubungan yang signifikan antara penggunaan media buku saku kesehatan reproduksi remaja dengan pelaksanaan Pemeriksaan Payudara Sendiri (SADARI) oleh responden, hal ini disebabkan karena persepsi tentang konsep sehat-sakit setiap individu berbeda-beda sehingga berpengaruh terhadap respon suatu tindakan individu tersebut.

Hal itu sesuai dengan teori Health-Belief Model kreasi Rosenstock dkk, bahwa ancaman suatu penyakit dipersepsikan secara berbeda oleh setiap individu, keputusan untuk mengambil tindakan/upaya pencegahan penyakit tergantung dari persepsi individu tentang keuntungan dari tindakan tersebut baginya, besar kecilnya hambatan untuk melaksanakan tindakan itu serta pandangan individu tentang kemampuan diri sendiri.

Untuk menguatkan keputusan bertindak, diperlukan faktor pencetus (berita dari media, ajakan orang yang dikenal atau ada yang mengingatkan). 
Jika faktor pencetus itu cukup kuat dan individu merasa siap, barulah individu itu benar-benar melaksanakan tindakan yang dianjurkan guna menanggulangi atau mencegah penyakit yang dideritanya.

Dalam konteks penelitian ini, diketahui penggunaan buku saku kesehatan reproduksi remaja tidak berpengaruh terhadap pelaksanaan Pemeriksaan Payudara Sendiri (SADARI) pada remaja. Penggunaan media buku saku kesehatan reproduksi remaja tidak signifikan karena ada faktor lain yang lebih berpengaruh.

Artinya penggunaan media buku saku kesehatan reproduksi remaja tidak bisa menjamin untuk bisa melaksanakan Pemeriksaan Payudara Sendiri (SADARI) pada remaja. Dampak penggunaan media cetak diantaranya adalah informasi dalam media cetak cenderung satu arah, sehingga jika ada kesalahan dalam informasi yang diberikan tidak dapat dengan cepat dilakukan klarifikasi.

\section{Simpulan}

Tidak terdapat hubungan yang signifikan antara penggunaan media buku saku kesehatan reproduksi dengan pelaksanaan Pemeriksaan Payudara Sendiri (SADARI).

Beberapa saran berikut ini agar menjadi pertimbangan bagi pihak terkait untuk meningkatkan pelaksanaan Pemeriksaan Payudara Sendiri (SADARI) di masyarakat pada umumnya dan di SMAN 1 Cipanas Kabupaten Lebak khususnya. Oleh karena itu, Pihak Sekolah supaya lebih memberikan dukungan dengan cara memfasilitasi kesehatan reproduksi remaja tidak hanya melalui media buku saku kesehatan reproduksi remaja tetapi juga mendukung dengan media lain seperti Pusat Informasi, Konseling Remaja \& Mahasiswa (PIK R/M) dan pemberian informasi melalui penyuluhan kesehatan reproduksi remaja secara periodik.

\section{Daftar Pustaka}

Adnani, H. 2011. Ilmu Kesehatan Masyarakat. Nuha Medika. Yogyakarta

Amalia, Lena. Mengobati Kanker Serviks dan 32 Jenis Kanker Lainnya. Landscape. Jogjakarta. 2009

Green, L.W. Health promotion Planning an Edukational and Environmental Approach, second adition. Mayfild Publising Company. USA. 1991 
Indrati, Rini. Faktor-Faktor Risiko yang Berpengaruh terhadap Kejadian Kanker Payudara Wanita. Jurnal Epidemiologi. 2005

Mangan, Yellia. Cara Bijak Menaklukan Kanker. Argo Media Pustaka. Jakarta. 2005

Manuaba, Ida A.S.K.D.S., dkk. Buku Ajar Ginekologi untuk Mahasiswa Kebidanan. EGC. Jakarta. 2009

Manuaba, Ida A.C. Memahami Kesehatan Reproduksi Wanita. EGC. Jakarta. 2009

Notoatmodjo. Pendidikan dan Prilaku Kesehatan. Rineka Cipta.Jakarta 2003

Penelitian kesehatan. Rineka Cipta. Jakarta 2003

- Promosi Kesehatan dan Aplikasinya. Rineka Cipta. Jakarta. 2005

Olfah, Yustiana, dkk. Kanker Payudara dan SADARI. Nuha Medika. Jogjakarta. 2013

Saifudin, Abdul Bari. Ilmu Kandungan. PT Bina Pustaka Sarwono Prawiroharjo. Jakarta. 2009

Septiani S, Suara M. Faktor - Faktor Yang Berhubungan Dengan Perilaku Pemeriksaan Payudara Sendiri (Sadari) Pada Siswa SMAN 62 Jakarta 2012

Sulastri, Thaha R, Russeng S. Pengaruh Penyuluhan

Kesehatan
Menggunakan Video dalam Pemeriksaan Payudara Sendiri (SADARI) terhadap Perubahan Pengetahuan dan Sikap Remaja Puteri di SMAN 9 Balikpapan Tahun 2012

Viviyawati, Tri. Pengaruh Pendidikan Kesehatan Tentang Pemeriksaan "SADARI" Sebagai Deteksi Dini Kanker Payudara Terhadap Pengetahuan dan Sikap Remaja Putri di SMKN 1 Karanganyar 